\title{
Synthesis of Minerals with Iron Oxide and Hydroxide Contents as a Sorption Medium to Remove Arsenic from Water for Human Consumption
}

\author{
Sofia Garrido-Hoyos ${ }^{1, *}$ and Lourdes Romero-Velazquez ${ }^{2}$
}

Received: 25 September 2015; Accepted: 15 December 2015; Published: 23 December 2015

Academic Editors: Ravi Naidu and Mohammad Mahmudur Rahman

1 Instituto Mexicano de Tecnología del Agua, Paseo Cuahnáhuac 8532, Col. Progreso, Jiutepec, CP. 62550

Morelos, México

2 Universidad Politécnica del Estado de Morelos, Paseo Cuauhnáhuac 566, Col. Lomas del Texcal, Jiutepec, CP. 62550 Morelos, México; ambiental.romero@gmail.com

* Correspondence: sgarrido@tlatloc.imta.mx; Tel.: +52-777-329-3600 (ext. 320)

\begin{abstract}
Arsenic has been classified as a toxic and carcinogenic chemical element. It therefore presents a serious environmental problem in different regions of the country and the world. In the present work, two adsorbent media were developed and evaluated to remove arsenic from water in the Pajaro Verde mine shaft, Huautla, Tlaquiltenango, Morelos. The media were synthesized and characterized, obtaining a surface area of $43.04 \mathrm{~m}^{2} \cdot \mathrm{g}^{-1}$ for the goethite and $2.44 \mathrm{~m}^{2} \cdot \mathrm{g}^{-1}$ for silica sand coated with $\mathrm{Fe}(\mathrm{III})$. To conduct the sorption kinetics and isotherms, a $2^{3}$ factorial design was performed for each medium in order to obtain the optimal conditions for the factors of arsenic concentration, $\mathrm{pH}$ and mass of the adsorbent. The best results were obtained for goethite, with a removal efficiency of $98.61 \%\left(\mathrm{C}_{0}\right.$ of $\left.\mathrm{As}(\mathrm{V}) 0.360 \mathrm{mg} \cdot \mathrm{L}^{-1}\right)$, and an effluent concentration of $0.005 \mathrm{mg} \cdot \mathrm{L}^{-1}$, a value that complies with the modified Official Mexican Standard NOM-127-SSA1-1994 [1] and WHO guidelines (2004) [2]. The kinetic equation that best fit the experimental data was the pseudo-second-order, resulting in the highest values for the constants for synthetic goethite, with a rate constant sorption of $4.019 \cdot \mathrm{g} \cdot \mathrm{mg}^{-1} \cdot \mathrm{min}^{-1}$. With respect to the sorption isotherms, both media were fitted to the Langmuir-II linear model with a sorption capacity $\left(\mathrm{q}_{\mathrm{m}}\right)$ of $0.4822 \mathrm{mg} \cdot \mathrm{g}^{-1}$ for goethite and $0.2494 \mathrm{mg} \cdot \mathrm{g}^{-1}$ for silica sand coated with Fe(III).
\end{abstract}

Keywords: arsenic; kinetic; experimental design; isotherm; adsorbent media

\section{Introduction}

The presence of arsenic in water results from the dissolution of minerals, geogenic activities, industrial effluents and the air. Nevertheless, other causes of arsenic in nature depend on anthropogenic activities such as the leaching of mine residues [3] and the use of insecticides. The degree of the toxicity of arsenic depends on the way in which it dissolves in the medium in which it is found. Arsenic is present in its four forms of oxidation, as arsenate $\left(\mathrm{As}^{5+}\right)$, arsenite $\left(\mathrm{As}^{3+}\right)$, arsine $\left(\mathrm{As}^{3-}\right)$ and its fundamental state $\left(\mathrm{As}^{0}\right)$. Generally, the form in which it is present in water bodies is its trivalent and pentavalent state, with $\mathrm{As}^{3+}$ being the most toxic [4].

In Mexico, several cases of groundwater contamination have presented themselves, one of which is located in the Huautla in the municipality of Tlaquiltenango, State of Morelos. Another case of contamination is present in the Comarca Lagoon, with values as high as $0.348 \mathrm{mg} \cdot \mathrm{L}^{-1}$, 14 times greater than the maximum limit permissible by the Mexican Standard NOM-127-SSA1-1994 and the WHO. In both of these locations, the water is frequently used as a source of supply for human consumption. 
The consumption of water contaminated with arsenic can produce cancerous diseases in a variety of organs in the body, including the lungs, kidneys, bladder, liver and skin, as well as hydroarsenicism [5]. The aim of this work was to develop and evaluate the efficiency of two different sorption media, characterized by their iron oxides and hydroxides contents, for the removal of $\mathrm{As}(\mathrm{V})$ from water for human consumption.

\section{Experimental Section}

\subsection{Preparation and Characterization of Adsorbent Media}

Two adsorbent media were developed, silica sand coated with Fe(III) and synthetic goethite, following the methods by Thirunavukkrasu et al. (2001) [6] and Garrido (2008) [7], respectively. The media were analyzed in a Micrometrics Model ASAP202 surface area and porosity analyzer. The size of the particulate was determined by granulometry method. The adsorbent materials were characterized by analysis of elemental composition with energy dispersive X-ray spectroscopy (EDXS), surface area and porosity using a Micrometrics Model ASAP 2020 (No Series: 831Norcross, GA, USA); the morphology of this media was analyzed by scanning electron microscopy (SEM) (Quanta 200, Hillsboro, OR, USA), with secondary electrons (SE) and back-scattered electrons detector (BSE), which determined chemical changes in the contrast images. Functional groups on the media, responsible for the sorption of arsenic, were determined using Fourier transform infrared spectroscopy (FTIR) (Thermo Scientific, Madison, WI, USA), Nicolet 6700 spectrometry brand with detector: DTGS KB.

\subsection{Batch Test}

The water used for the batch tests was obtained from the Pájaro Verde mine shaft, in Huautla, the municipality of Tlaquiltenango, Morelos (Table 1). It was characterized using Mexican Standards and Standard Methods (2013) [8].

Table 1. Huautla mine shaft water quality.

\begin{tabular}{ccc}
\hline Parameters & Units & Value \\
\hline Physical & & \\
\hline Total dissolved solids & $\mathrm{mg} \cdot \mathrm{L}^{-1}$ & 226 \\
Electrical conductivity & $\mu \mathrm{S} \cdot \mathrm{cm}^{-1}$ & 452 \\
Turbidity & $\mathrm{UTN}$ & 19 \\
True color & $\mathrm{UPt}-\mathrm{Co}$ & 2 \\
\hline Chemical & & \\
\hline Total hardness & $\mathrm{mg} \cdot \mathrm{L}^{-1} \mathrm{CaCO}_{3}$ & 179.9 \\
pH & & 8.57 \\
Redox potential & $\mathrm{mV}$ & 233 \\
Bicarbonates & $\mathrm{mg} \cdot \mathrm{L}^{-1}$ & 221 \\
Chlorides & $\mathrm{mg} \cdot \mathrm{L}^{-1}$ & 2.4 \\
O-Phosphates & $\mathrm{mg} \cdot \mathrm{L}^{-1}$ & 0.45 \\
Nitrates & $\mathrm{mg} \cdot \mathrm{L}^{-1}$ & 6.3 \\
Sulphates & $\mathrm{mg} \cdot \mathrm{L}^{-1}$ & 14 \\
Arsenic & $\mathrm{mg} \cdot \mathrm{L}^{-1}$ & 0.196 \\
Calcium & $\mathrm{mg} \cdot \mathrm{L}^{-1}$ & 35.49 \\
Magnesium & $\mathrm{mg} \cdot \mathrm{L}^{-1}$ & 3.06 \\
\hline
\end{tabular}

Batch adsorption kinetics was performed in a Jar Tester Phillips \& Birds with agitation at $120-200 \mathrm{rpm}$ at $25{ }^{\circ} \mathrm{C}$ [9]. The $\mathrm{As}(\mathrm{V})$ concentrations were prepared with sodium arsenate heptahydrate $\left(\mathrm{Na}_{2} \mathrm{HAsO}_{4} \cdot 7 \mathrm{H}_{2} \mathrm{O}, 98 \%\right.$ purity, (Sigma-Aldrich: Milwaukee, WI, USA), to reached the different values of the experimental design. The $\mathrm{pH}$ was maintained by adjusting with $\mathrm{NaOH}$. Between 1 and $2 \mathrm{~L}$ of water was taken from Huautla mine shaft, to which were added different media 
masses, between 1.0 and $4 \mathrm{~g}$. Samples were taken at time intervals of $25 \mathrm{~min}$. The sample was filtered using a $0.45 \mu \mathrm{m}$ membrane and the parameters arsenic and $\mathrm{pH}$ were analyzed. Arsenic was determined using the Wagtech photometer method [10,11]. The experiments were carried out using a $2^{3}$ factorial design for each medium with the program Statgraphics Centurion XVI, version 2012, obtaining a matrix containing 10 experimental tests. The factors evaluated were arsenic concentration, $\mathrm{pH}$ and mass of the adsorbent medium (Table 2).

Table 2. Experimental design for the batch test.

\begin{tabular}{cccccccc}
\hline \multirow{2}{*}{ Factors } & \multicolumn{3}{c}{ Silica Sand Coated with Fe(III) } & \multicolumn{3}{c}{ Goethite } \\
\cline { 2 - 7 } & $\mathbf{+ 1}$ & $\mathbf{0}$ & $\mathbf{- 1}$ & $\mathbf{+ 1}$ & $\mathbf{0}$ & $\mathbf{- 1}$ \\
\hline As concentration $\left(\mathrm{mg} \cdot \mathrm{L}^{-1}\right)$ & 0.392 & 0.294 & 0.196 & 0.360 & 0.278 & 0.196 \\
$\mathrm{pH}$ & 8.5 & 8 & 7.5 & 8.5 & 8 & 7.5 \\
Adsorbent mass $(\mathrm{g})$ & 4 & 3 & 2 & 2 & 1.5 & 1 \\
\hline
\end{tabular}

The quantity of arsenic adsorbed was deduced from the initial concentration using the equation:

$$
q=\frac{V\left(C_{0}-C_{e}\right)}{2}
$$

where $q$ is the measured sorption per unit weight of solid, $V$ is the volume of the solution, $C_{0}$ and $C_{e}$ are the initial and equilibrium concentrations of arsenic, respectively, and $M$ is the dry weight of the biosorbent.

To calculate the kinetic sorption constants, the experimental data were fit to a pseudo-second-order equation. For isotherms, the data were adjusted to the Langmuir (I) and (II) and Freundlich models.

\section{Results and Discussion}

Table 3 shows the results of the analysis of the composition of silica sand coated with Fe(III) and goethite. The primary elements present in both media are carbon $(\mathrm{C})$, oxygen $(\mathrm{O})$ and iron $(\mathrm{Fe})$ with the highest content. Aluminum and silica compounds were found as constituents of the silica sand.

Table 3. Elemental analysis of adsorbents.

\begin{tabular}{ccc}
\hline \multirow{2}{*}{ Element } & \multicolumn{2}{c}{ Percentage by Weight (\%) } \\
\cline { 2 - 3 } & Silica Sand Coated with Fe(III) & Goethite \\
\hline C & 18.57 & 15.50 \\
$\mathrm{O}$ & 38.77 & 33.68 \\
$\mathrm{Al}$ & 0.63 & - \\
$\mathrm{Si}$ & 9.77 & - \\
$\mathrm{Fe}$ & 32.25 & 50.82 \\
\hline
\end{tabular}

Table 4 shows the characterization of the adsorbent media used in the batch tests. The surface area of goethite was observed to be 17 times greater than that of silica sand coated with Fe(III); both media were classified as mesoporous. In previous studies, such as that of Garrido (2008) [7], the greatest amount of $\mathrm{As}(\mathrm{V})$ found in water in Huautla was species $\mathrm{HASO}_{4}{ }^{2-}$, according to the species diagram at $\mathrm{pH} 8.57$ [9], with a radius of $3.97 \AA$. Therefore, the diameters of both media were porous enough for the $\mathrm{As}^{5+}$ molecule to enter. 
Table 4. Characterization of the adsorbent media obtained in the laboratory.

\begin{tabular}{cccc}
\hline Analysis & Units & Silica Sand Coated with Fe(III) & Goethite \\
\hline Surface area & $\mathrm{m}^{2} \cdot \mathrm{g}^{-1}$ & 2.44 & 43.04 \\
Accumulated micropore volume & $\mathrm{cm}^{3} \cdot \mathrm{g}^{-1}$ & 0.002 & 0.12 \\
Average pore diameter & $\mathrm{A}$ & 53.60 & 119.05 \\
Pore structure & & Mesoporous & Mesoporous \\
Particulate size & $\mathrm{mm}$ & $0.3-0.6$ & $0.1-0.6$ \\
\hline
\end{tabular}

Scanning electron microscopy (SEM) was used to study the morphological structure of the two media. In Figure $1 \mathrm{a}-\mathrm{c}$, the images of silica sand coated with $\mathrm{Fe}(\mathrm{III})$ untreated are presented. In these images the surface amorphous structure is shown. In Figure $2 a-c$, the SEM images of synthetic goethite, which is a material of different sizes, are observed at $2000 \times$; when this is viewed at higher magnifications of $5000 \times$ and $1000 \times$, very fine fibers that are less than $5 \mu \mathrm{m}$ with crystalline materials of spherical structure are shown.
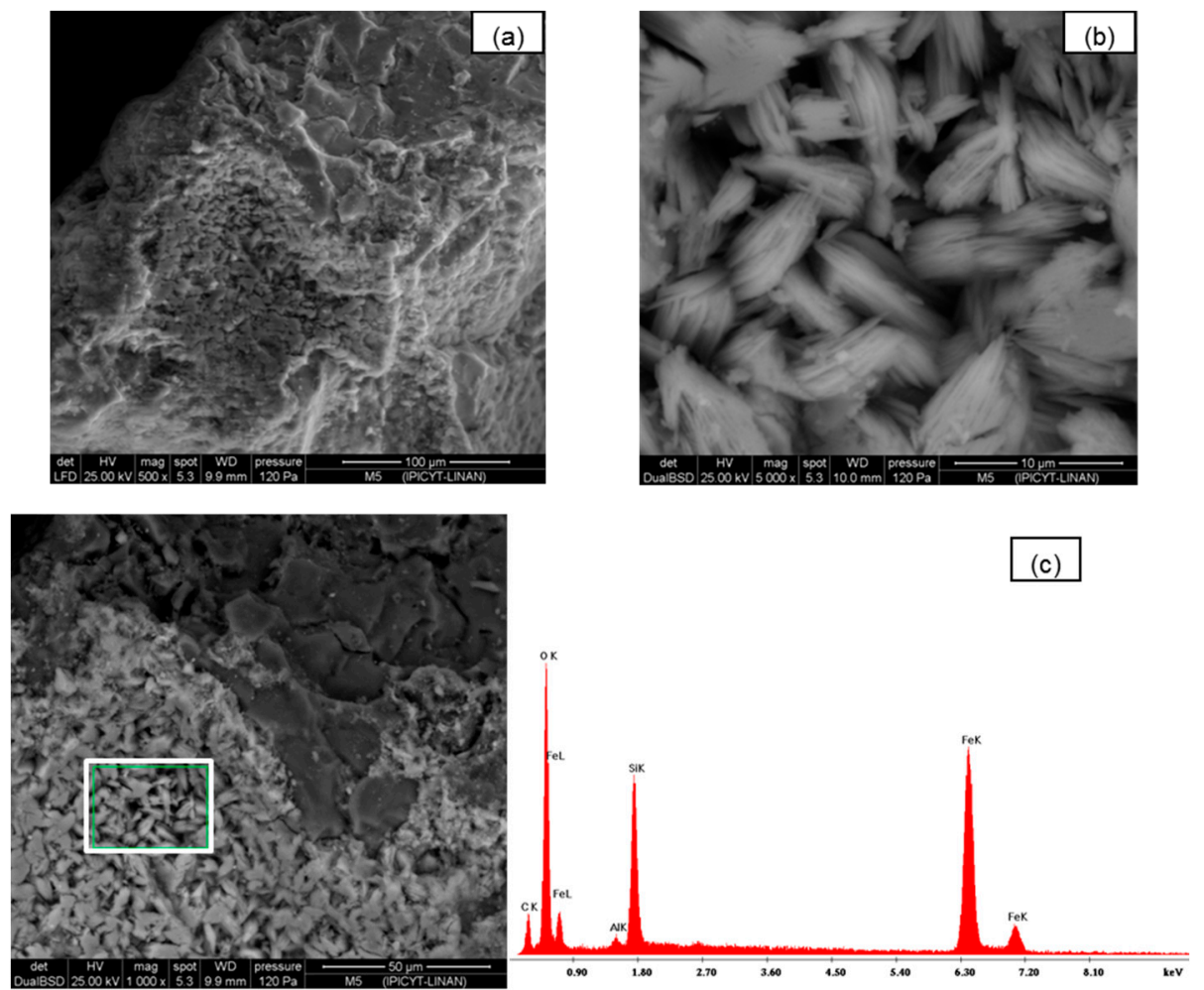

Figure 1. (a,b) SEM images of silica sand coated with Fe(III) untreated; (c) Fragment where EDS (white box) and chemical spectrograph quantification EDS of adsorbent was performed.

The infrared spectra (IR) from silica sand coated with Fe(III) in the absence and presence of $\operatorname{As}(\mathrm{V})$, as shown in Figure 3, were used to analyze the presence of the main sorption functional groups. It is noted that the two spectra are very similar. The small peak at $1635 \mathrm{~cm}^{-1}$ indicates the presence of free water molecules and water molecules bonded onto silica. The intense band at $1160 \mathrm{~cm}^{-1}$ is characteristic of $\mathrm{Si}-\mathrm{O}$ bonds as is the peak noticeable at $800 \mathrm{~cm}^{-1}$. The band in the presence of As $(\mathrm{V})$ between 600 and $520 \mathrm{~cm}^{-1}$ belongs to the stretching mode Fe-O, and Fe-O-As, small shoulder, respectively [12].

Figure 4 shows the spectrum (IR) from goethite in the absence and presence of $\mathrm{As}(\mathrm{V})$. It is noted that the two spectra are very similar. The region of $3500-3000 \mathrm{~cm}^{-1}$ reveals a very high increase in $\mathrm{O}-\mathrm{H}$ stretching with for both bands. The band in the absence and presence of $\mathrm{As}(\mathrm{V})$ between 600 
and $520 \mathrm{~cm}^{-1}$ belongs to the stretching mode Fe-O [12]. The band at $780-800 \mathrm{~cm}^{-1}$ observed in the presence of arsenic can be assigned to the As-OH stretching [12,13]. It may be due to the sorption of $\mathrm{HAsO}^{2-}$ on goethite.
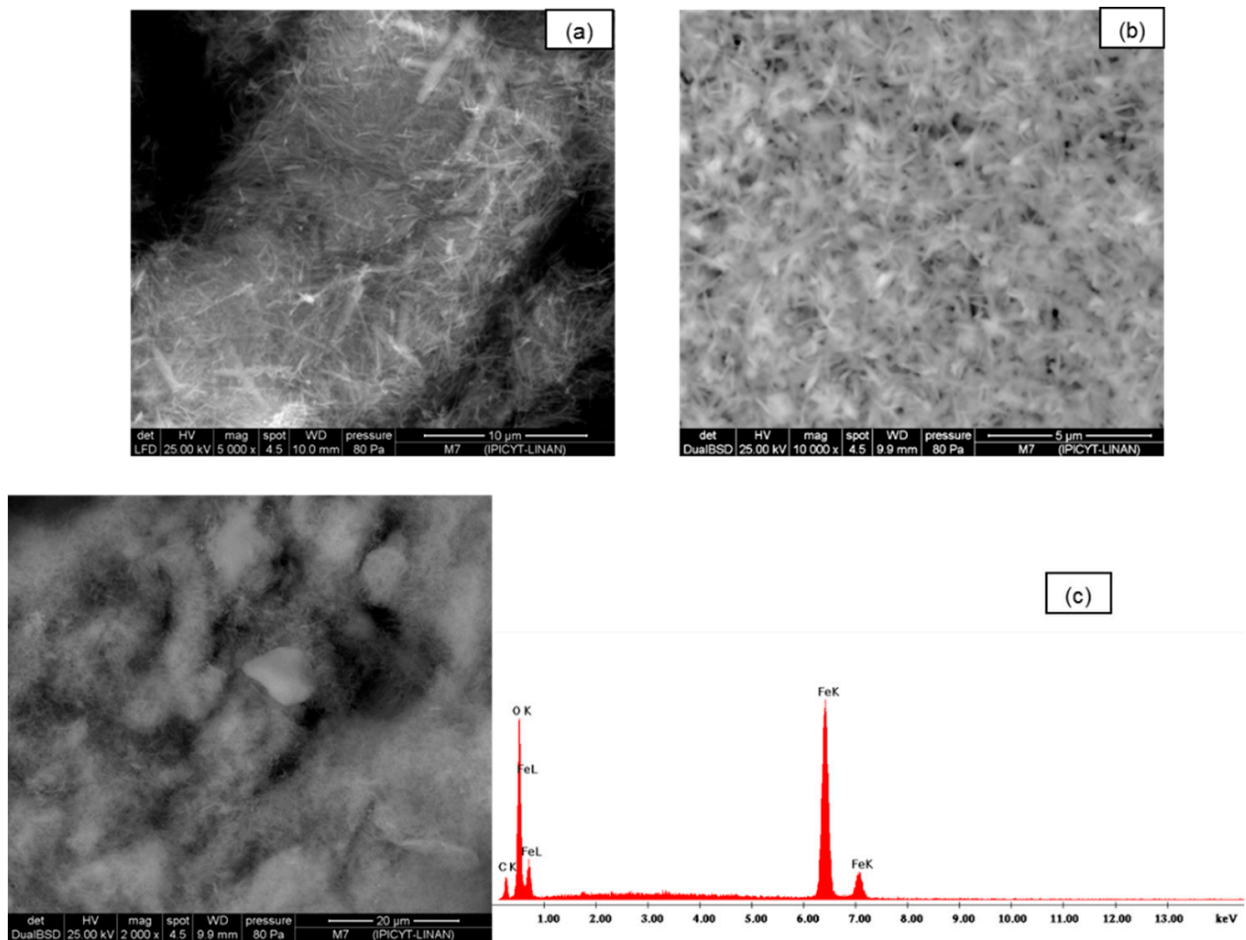

Figure 2. (a,b) SEM images of goethite untreated; (c) Chemical spectrograph quantification EDS of adsorbent was performed.

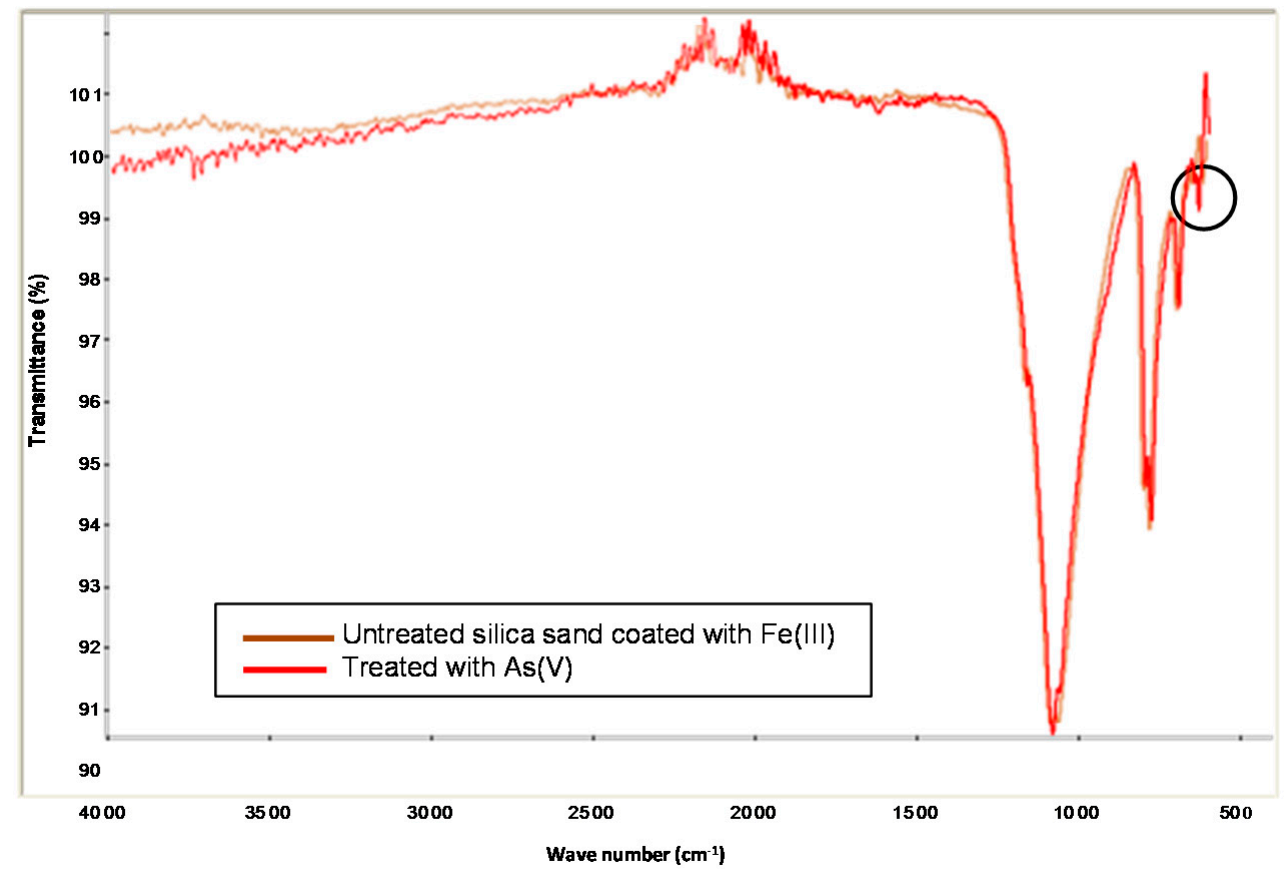

Figure 3. FTIR spectrum of silica sand coated with Fe(III) in absence and presence of As(V). 


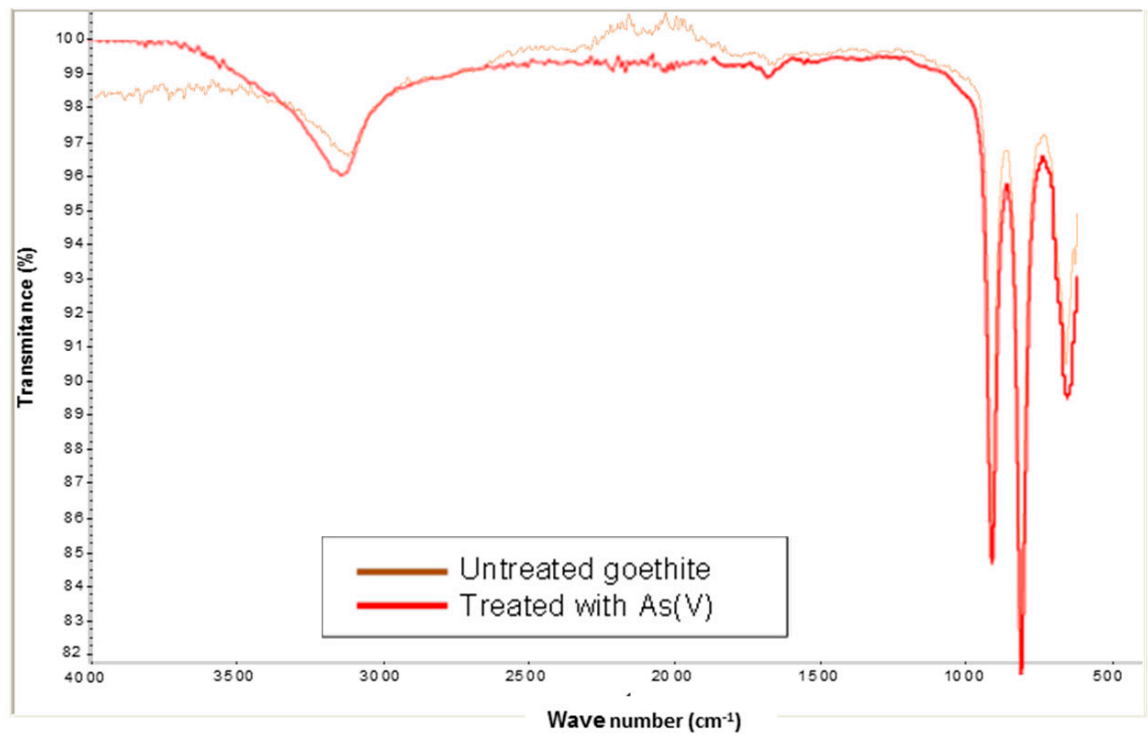

Figure 4. FTIR spectrum of goethite in absence and presence of As(V).

Based on the design of the experiments, a statistically significant difference $(p<0.005)$ was found for the two adsorbent media for the initial concentration of arsenic, while a statistically significant difference $(p<0.005)$ for mass was shown only for goethite. The optimal conditions obtained for silica sand coated with $\mathrm{Fe}(\mathrm{III})$ were: As concentration of $0.392 \mathrm{mg} \cdot \mathrm{L}^{-1}, \mathrm{pH}$ of 8.5 and mass of $4 \mathrm{~g} \cdot \mathrm{L}^{-1}$. Those for goethite were: As concentration of $0.360 \mathrm{mg} \cdot \mathrm{L}^{-1}, \mathrm{pH}$ of 7.5 and mass of $2.0 \mathrm{~g} \cdot \mathrm{L}^{-1}$. The sorption kinetics for the two media is shown in Figures 5 and 6.

To quantify the changes in sorption with respect to the time required by a suitable kinetic model, we use the pseudo-second-order equation:

$$
\frac{t}{q_{t}}=\frac{1}{k_{a d} q_{e}^{2}}+\frac{1}{q_{e}} t
$$

where $q_{t}$ is the sorption capacity $\left(\mathrm{mg} \cdot \mathrm{g}^{-1}\right), q_{e}$ is the sorption capacity in equilibrium $\left(\mathrm{mg} \cdot \mathrm{g}^{-1}\right)$, $k_{a d}$ is the rate constant of sorption $\left(\mathrm{g} \cdot \mathrm{mg}^{-1} \cdot \mathrm{min}^{-1}\right)$ and $h$ is the initial sorption rate $\left(\mathrm{mg} \cdot \mathrm{g}^{-1} \cdot \mathrm{min}^{-1}\right)$ at $\mathrm{t}=0$ :

$$
h=k_{a d} q_{e}^{2}
$$

Figures 5 and 6 show the $\mathrm{As}(\mathrm{V})$ kinetics sorption for silica sand coated with Fe(III) and goethite.

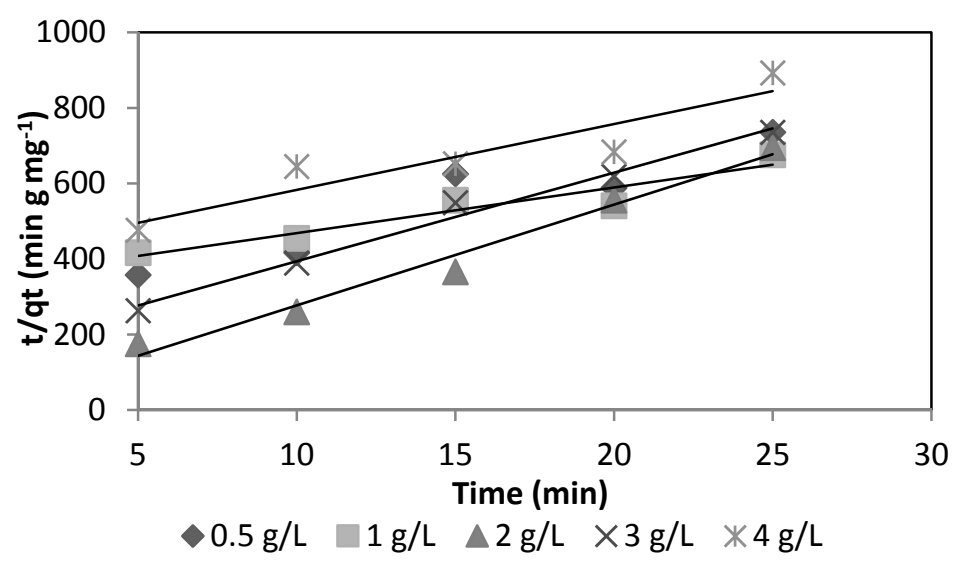

Figure 5. Kinetic sorption of $\mathrm{As}(\mathrm{V})$ for silica sand coated with Fe(III). 


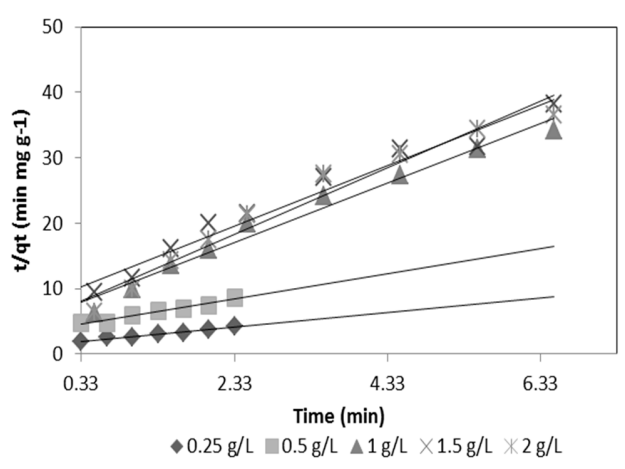

Figure 6. Kinetic sorption of $\mathrm{As}(\mathrm{V})$ for goethite.

Table 5 shows that the rate constant of sorption $\left(\mathrm{k}_{\mathrm{ad}}\right)$ for goethite is 5.39 times greater than the $\mathrm{k}_{\mathrm{ad}}$ for silica sand coated with $\mathrm{Fe}(\mathrm{III})$ and, therefore, synthesized goethite has a greater sorption capacity due to its larger surface area as compared to silica sand coated with Fe(III). It can be seen that the initial sorption rate $(\mathrm{h})$ of goethite is higher than the silica sand coated with Fe(III). Studies conducted by Thirunavukkarasu et al. $(2001 ; 2003)[6,14]$ and Paredes (2012) [9] determined $k_{a d}$ values of 0.033 and $7.409 \mathrm{~g} \cdot \mathrm{mg}^{-1} \mathrm{~min}^{-1}$ for granular iron hydroxide and goethite, respectively.

Table 5. Pseudo-second-order kinetic sorption constants.

\begin{tabular}{cccc}
\hline & Units & Silica Sand Coated with Fe (III) & Goethite \\
\hline Mass & $(\mathrm{g})$ & 4 & 2 \\
$\mathrm{qe}_{\mathrm{e}}$ & $\mathrm{mg} \cdot \mathrm{g}^{-1}$ & 0.058 & 0.196 \\
$\mathrm{k}_{\mathrm{ad}}$ & $\left(\mathrm{g} \cdot \mathrm{mg}^{-1} \cdot \mathrm{min}^{-1}\right)$ & 0.745 & 4.019 \\
$\mathrm{~h}$ & $\left(\mathrm{mg} \cdot \mathrm{g}^{-1} \cdot \mathrm{min}^{-1}\right)$ & 0.0024 & 0.155 \\
\hline
\end{tabular}

The sorption isotherms of arsenate using silica sand coated with $\mathrm{Fe}(\mathrm{III})$ and goethite at $\mathrm{pH} 8.5$ and 7.5, respectively, are shown in Figures 7 and 8 and the isotherm constants are shown in Table 6 . For both, adsorption takes place according to the Langmuir model, type (II):

$$
q_{e}=\frac{q_{m} b C_{e}}{1+b C_{e}}
$$

Langmuir (II)

$$
\frac{1}{q_{e}}=\frac{1}{q_{m}}+\left(\frac{1}{b q_{m}}\right)+\left(\frac{1}{C_{e}}\right)
$$

where $q_{e}$ is the sorption capacity in the equilibrium $\left(\mathrm{mg} \cdot \mathrm{g}^{-1}\right), q_{m}$ is the maximum sorption capacity $\left(\mathrm{mg} \cdot \mathrm{g}^{-1}\right), C_{e}$ is the concentration in equilibrium $\left(\mathrm{mg} \cdot \mathrm{L}^{-1}\right)$ and $b$ is the constant related with the energy.

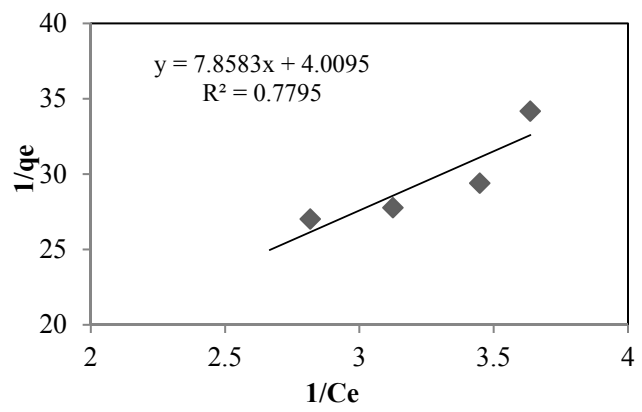

Figure 7. Langmuir (II) isotherm for silica sand coated with Fe(III). As $s_{\text {initial }}: 0.392 \mathrm{mg} \cdot \mathrm{L}^{-1}$. T: $22{ }^{\circ} \mathrm{C}$. 


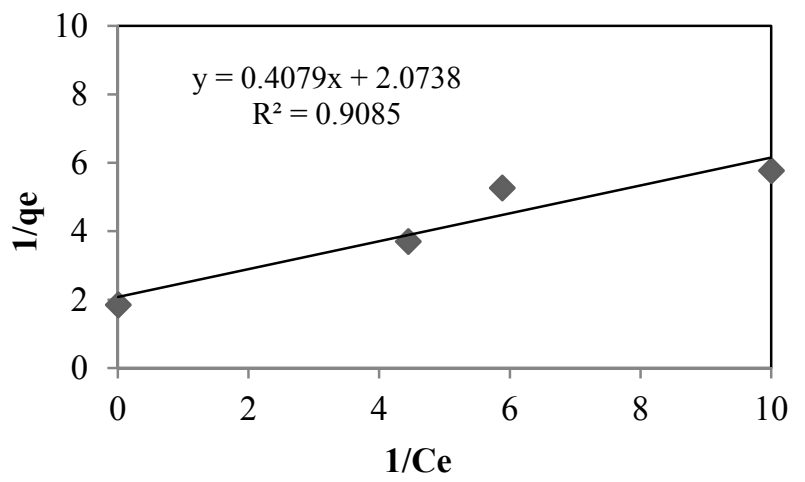

Figure 8. Langmuir (II) isotherm for goethite. As initial$: 0.360 \mathrm{mg} \cdot \mathrm{L}^{-1}$. T: $22{ }^{\circ} \mathrm{C}$.

Table 6. Langmuir (II) isotherm constants.

\begin{tabular}{cccc}
\hline & Units & Silica Sand Coated with Fe (III) & Goethite \\
\hline $\mathrm{qm}_{\mathrm{m}}$ & $\left(\mathrm{mg} \cdot \mathrm{g}^{-1}\right)$ & 0.2494 & 0.4822 \\
$\mathrm{~b}$ & - & 0.5102 & 5.0841 \\
$R^{2}$ & - & 0.7795 & 0.9085 \\
\hline
\end{tabular}

A comparison of the removal capacities of the selected sorbent materials towards $\mathrm{As}(\mathrm{V})$ is given in Table 7. The $\mathrm{As}(\mathrm{V})$ uptake determined in this work was higher than: iron oxide-coated sand (IOCS) ferrihydrite (FH) for goethite and granular ferric hydroxide (GFH). The goethite adsorbent seems to be a good alternative for the removal of $\mathrm{As}(\mathrm{V})$ species from an aqueous systems.

Table 7. A comparison of the produced materials' $\mathrm{As}(\mathrm{V})$ sorption capacity $\left(\mathrm{q}_{\mathrm{m}}\right)$ with data from the literature, and the best fit Langmuir isotherm model.

\begin{tabular}{|c|c|c|c|c|}
\hline Adsorbent & $\mathrm{C}_{\mathrm{o}}\left(\mathrm{mg} \cdot \mathrm{L}^{-1}\right)$ & $\mathrm{pH}$ & $\mathrm{q}_{\mathrm{m}}\left(\mathrm{mg} \cdot \mathrm{g}^{-1}\right)$ & Reference \\
\hline Silica sand coated with Fe(III) & 0.392 & 8.5 & 0.2494 & This study \\
\hline Goethite synthesized & 0.360 & 7.5 & 0.4822 & This study \\
\hline Natural goethite & 0.220 & 7.5 & 9.30 & [15] \\
\hline Iron oxide coated sand (IOCS) & 0.325 & 7.4 & 0.183 & [6] \\
\hline Ferrihydrite $(\mathrm{FH})$ & - & - & 0.285 & [6] \\
\hline Crystalline hydrous ferric oxide (CHFO) & 50 & - & 25 & [16] \\
\hline Granular ferric hydroxide (GFH) & 0.50 & 7.6 & 0.159 & [14] \\
\hline Sulphuric acid acidified laterite (ALS) & 0.1 & 7.0 & 0.923 & [17] \\
\hline Silica coated with Fe oxides (8\%) & 50 & 5.0 & 30.59 & [17] \\
\hline Silica coated with Al oxides ( $8 \%)$ & 50 & 4.0 & 6.52 & [17] \\
\hline
\end{tabular}

\section{Conclusions}

The adsorbent media with a more efficient removal of arsenic (98.61\%) was goethite synthesized in the laboratory. The arsenic concentration obtained in the effluent was $0.005 \mathrm{mg} / \mathrm{L}$, a value that complies with the Mexican norm NOM-127-SSA-1994 and WHO guidelines (2004). When fitting the experimental data to a pseudo-second-order equation, the kinetic sorption study shows goethite to have a high rate constant of sorption $\left(\mathrm{k}_{\mathrm{ad}}\right)$ as compared to other investigations. This is also seen for the maximum sorption capacity $\left(\mathrm{q}_{\mathrm{m}}\right)$ obtained by applying the Langmuir model type (II).

Acknowledgments: This research was supported by Instituto Mexicano de Tecnología del Agua.

Author Contributions: Synthesis of irons oxides-hydroxides adsorbents to remove arsenic from the drinking water.

Conflicts of Interest: The authors declare no conflict of interest. 


\section{References}

1. Norma Oficial Mexicana. Salud Ambiental. Agua Para Uso Y Consumo Humano. Límites Permisibles De Calidad Y Tratamientos A Que Debe Someterse El Agua Para Su Potabilización; NOM-127-SSA1-1994; Diario Oficial de la Federación: Ciudad de Mexico, México, 2000.

2. WHO. Guidelines for Drinking Water Quality, 3rd ed.; World Health Organization: Geneva, Switzerland, 2004; Volume 1, p. 515.

3. Armienta, M.A.; Rodriguez, R.; Aguayo, A.; Ceniceros, N.; Villaseñor, G.; Cruz, O. Arsenic contamination of ground water at Zimapan, Mexico. Hydrogeol. J. 1997, 5, 39-46.

4. Jiménez, C. La Contaminación Ambiental En México; Editorial Limusa: Ciudad de México México, 2001; p. 926.

5. Gaioli, M.; González, D.E.; Amoedo, D. Chronic endemic regional hydroarsenicism: A challenge for diagnosis and prevention. Arch. Argent. Pediatr. 2009, 107, 459-473.

6. Thirunavukkarasu, O.S.; Viraraghavan, T.; Subramanian, K.S. Removal of arsenic drinking water by iron oxide coated sand and ferrihydrate batch studies. Water Qual. Res. J. Can. 2001, 36, 55-70.

7. Garrido, S.E. Origen Hidrogeológico Del Arsénico, Métodos Alternativos Innovativos Para Su Cuantificación Y Tratamiento. Available online: https://www.imta.gob.mx/historico/instituto/ historial-proyectoswrp/tc/2008/fi-tc0553-6.pdf (accessed on 18 December 2015).

8. Federation, W.E. Standard Methods for Examination of Water and Wastewater, 22th ed.; American Public Health Association: New York, NY, USA, 2013.

9. Paredes, J.L. Remoción de Arsénico del Agua Para Uso Y Consumo Humano Mediante Diferentes Materiales de Adsorción. Master's Thesis, Universidad Nacional Autónoma de México, Ciudada de México, México, 2012; p. 106.

10. Garrido, S.; Avilés, M.; Ramírez, A.; Calderón, C.; Ramírez-Orozco, A.; Nieto, A.; Shelp, G.; Seed, L.; Cebrian, M.; Vera, E. Arsenic removal from water of Huautla, Morelos, Mexico using Capacitive deionization. In Natural arsenic in Groundwaters. of Latin. America; Taylor \& Francis Group: London, UK, 2009; pp. 665-676.

11. Avilés, M.; Sofía, E.G.; José, S.; de La, P.; Cristina, N.; Ma, V.E. Removal of groundwater arsenic using a household filter with iron spikes and stainless steel. J. Environ. Manag. 2013, 131, 103-109.

12. Bordoloi, S.; Nath, S.K.; Gogoi, S.; Dutta, R.K. Arsenic and iron removal from groundwater by oxidation-coagulation at optimized pH: Laboratory and field studies. J. Hazard. Mater. 2013, 260, 618-626. [CrossRef] [PubMed]

13. Goldberg, S.; Johnstony, C.T. Mechanisms of arsenic sorption on amorphous oxides evaluated using macroscopic measurements vibrational spectroscopy, and surface complexation modelling. J. Colloid Interface Sci. 2001, 234, 204-216. [CrossRef] [PubMed]

14. Thirunavukkarasu, O.S.; Viraraghavan, T.; Subramanian, K.S. Arsenic removal from drinking water using granular ferric hydroxide. Water SA 2003, 29, 161-170. [CrossRef]

15. Garrido, S.E.; Romero, L. Synthesis of adsorbents with iron oxide and hydroxide contents for the removal of arsenic from water for human consumption. In One Century of the Discovery of Arsenicosis in Latin America (1914-2014); Taylor \& Francis Group: London, UK, 2014; pp. 693-695.

16. Biswa, R.M.; Sushanta, D.; Soumen, D.; Uday, C.G. Removal of Arsenic from Groundwater using Crystalline Hydrous Ferric Oxide (CHFO). Water Qual. Res. J. Can. 2003, 38, 193-210.

17. Yoann, G.; Ahmad, B.A.; José, G.; Eghe, O.; Chirangano, M.; Claire, G.; Stephen, J.A.; Gavin, M.W. Adsorption study using optimised 3D organised mesoporous silica coated with Fe and Al oxides for specific $\mathrm{As}(\mathrm{III})$ and $\mathrm{As}(\mathrm{V})$ removal from contaminated synthetic groundwater. Microporous Mesoporous Mater. 2014, 198, 101-114.

(C) 2015 by the authors; licensee MDPI, Basel, Switzerland. This article is an open access article distributed under the terms and conditions of the Creative Commons by Attribution (CC-BY) license (http://creativecommons.org/licenses/by/4.0/). 